\title{
Draft genome sequence of Mesotoga strain PhosAC3, a mesophilic member of the bacterial order Thermotogales, isolated from a digestor treating phosphogypsum in Tunisia
}

\author{
Wajdi Ben Hania ${ }^{1,2}$, Khaled Fadhlaoui ${ }^{1,2}$, Céline Brochier-Armanet ${ }^{3}$, Cécile Persillon ${ }^{4}$, Anne Postec ${ }^{1}$, Moktar Hamdi ${ }^{2}$, \\ Alain Dolla ${ }^{5}$, Bernard Ollivier ${ }^{1}$, Marie-Laure Fardeau ${ }^{1}$, Jean Le Mer $^{1}$ and Gaël Erauso ${ }^{1 *}$
}

\begin{abstract}
Mesotoga strain PhosAc3 was the first mesophilic cultivated member of the order Thermotogales. This genus currently contain two described species, M. prima and M. infera. Strain PhosAc3, isolated from a Tunisian digestor treating phosphogypsum, is phylogenetically closely related to M. prima strain MesG1.Ag.4.2 ${ }^{\top}$. Strain PhosAc3 has a genome of 3.1 Mb with a $\mathrm{G}+\mathrm{C}$ content of $45.2 \%$. It contains 3,051 protein-coding genes of which $74.6 \%$ have their best reciprocal BLAST hit in the genome of the type species, strain MesG1.Ag.4.2 $2^{\top}$. For this reason we propose to assign strain PhosAc3 as a novel ecotype of the Mesotoga prima species. However, in contrast with the M. prima type strain, (i) it does not ferment sugars but uses them only in the presence of elemental sulfur as terminal electron acceptor, (ii) it produces only acetate and $\mathrm{CO}_{2}$ from sugars, whereas strain MesG1.Ag.4.2 ${ }^{\top}$ produces acetate, butyrate, isobutyrate, isovalerate, 2-methyl-butyrate and (iii) sulfides are also end products of the elemental sulfur reduction in theses growth conditions.
\end{abstract}

Keywords: Anaerobic, Mesophilic, Thermotogales, Mesotoga

\section{Introduction}

Members of the order Thermotogales typically possess a sheath-like structure called a "toga" and are mostly known as thermophilic or hyperthermophilic bacteria. Most species within this order have been isolated from heated sub-seafloors, marine hydrothermal vents, terrestrial hot springs and oil field reservoirs. Interestingly, SSU rRNA genes of Thermotogales were also detected in samples from polluted environments such as sediments of harbors and sludge from waste water treatment plants [1]. Accordingly they were also found in mesothermic enrichment cultures, notably those capable of (i) reductively dechlorinating 2, 3, 4, 5-tetrachlorobiphenyl, (ii) oxidizing hydrocarbons [2]. We reported in 2011 the first cultivation and a preliminary description of a mesophilic bacterium pertaining to the Thermotogales (strain

\footnotetext{
* Correspondence: gael.erauso@mio.osupytheas.fr

'Aix-Marseille Université, Université du Sud Toulon-Var, CNRS/INSU, IRD, Mediterranean Institute of Oceanography (MIO), UM 110, F-13288, Marseille cedex 09, France

Full list of author information is available at the end of the article
}

PhosAc3) which was tentatively named "Mesotoga sulfurireducens" [3]. This mesophilic isolate was shown to belong to a large group of uncultivated bacteria that is distantly related to the thermophilic genus Kosmotoga. Soon after, M. prima strain MesG1.Ag.4. $2^{\mathrm{T}}$ isolated from sediments from Baltimore Harbor [4] and M. infera strain $\mathrm{VNs} 100^{\mathrm{T}}$ isolated from a water sample collected in the area of an underground gas storage [5] were fully characterized and described as new species. Strain PhosAc3 was isolated from a digestor treating phosphogypsum inoculated with a mixture of marine sediments and sludge originating from a dump and a wastewater treatment plant in Tunisia. It grows at temperatures between $30^{\circ} \mathrm{C}$ and $50^{\circ} \mathrm{C}$ (optimum $40^{\circ} \mathrm{C}$ ) and uses fructose and lactate as energy sources. Phylogenetic analyses based on 16S rRNA gene sequences revealed that strain PhosAc3 is closely related to $M$. prima strain MesG1.Ag.4.2 ${ }^{\mathrm{T}}$ [3]. 
Here we report on further taxonomic and physiological studies on strain PhosAc3 and describe the draft genome sequence and its annotation. We show that while they belong to the same species, PhosAc3 and MesG1.Ag.4.2 ${ }^{\mathrm{T}}$ strains exhibit significant phenotypic and metabolic differences and that their genomes differ by about $25 \%$ in gene content.

\section{Organism information}

Classification and features

Genomic sequences of strain PhosAc3 showed that it possesses two copies of the $16 \mathrm{~S}$ rRNA gene. As for M. infera, the two $16 \mathrm{~S}$ rRNA coding genes found in PhosAc3 are $100 \%$ identical (this was further

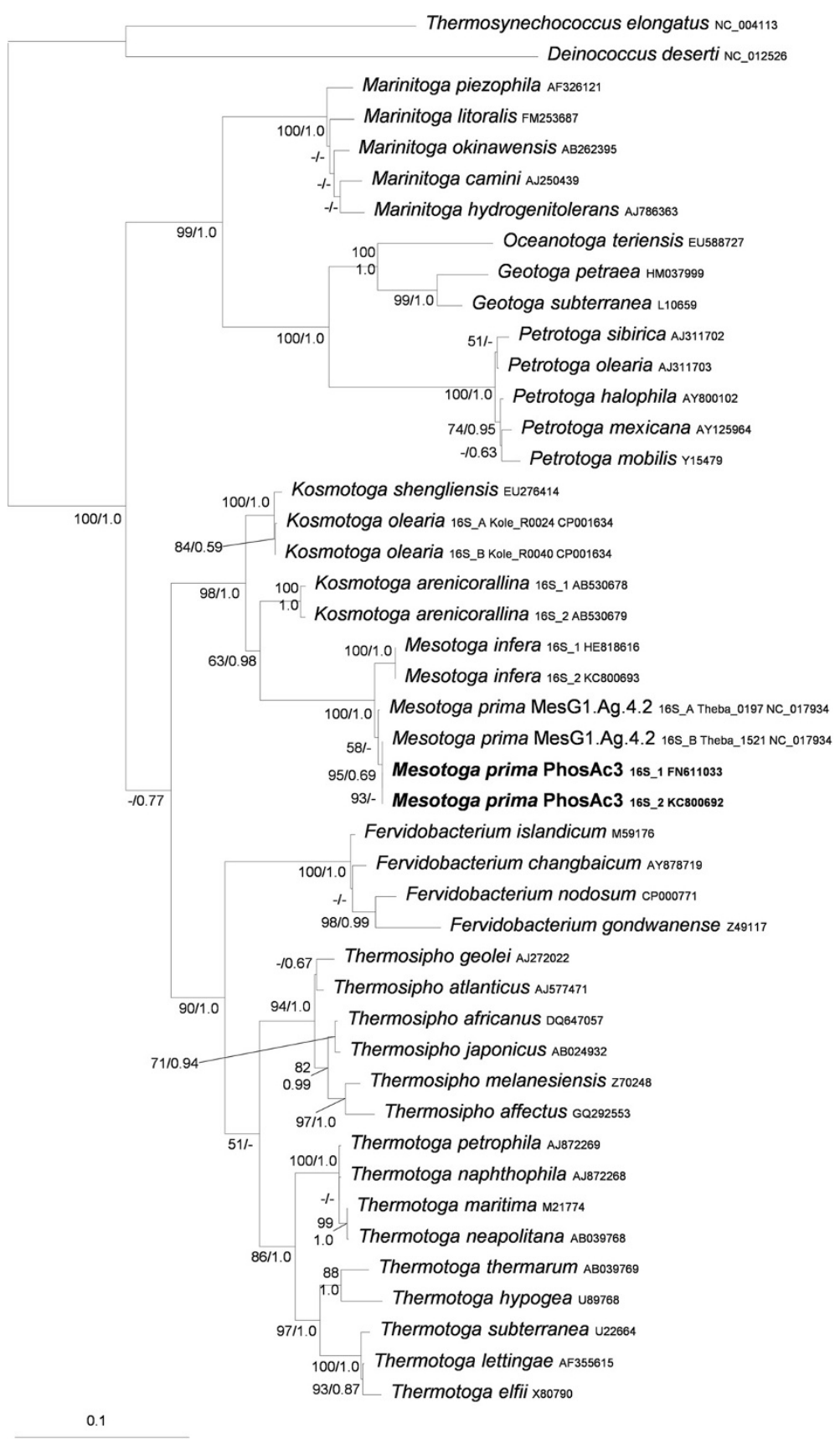

Figure 1 Rooted maximum likelihood phylogeny of SSU rRNA sequences from Thermotogales (45 sequences, 1265 nucleotide positions). Numbers at nodes represent the bootstrap values estimated by the non-parametric bootstrap procedure implemented in Treefinder (100 replicates of the original alignments) and the posterior probabilities computed by Mr Bayes (only values greater than $50 \%$ and 0.5 respectively, are shown). The scale bar represents the average number of substitution per site. 


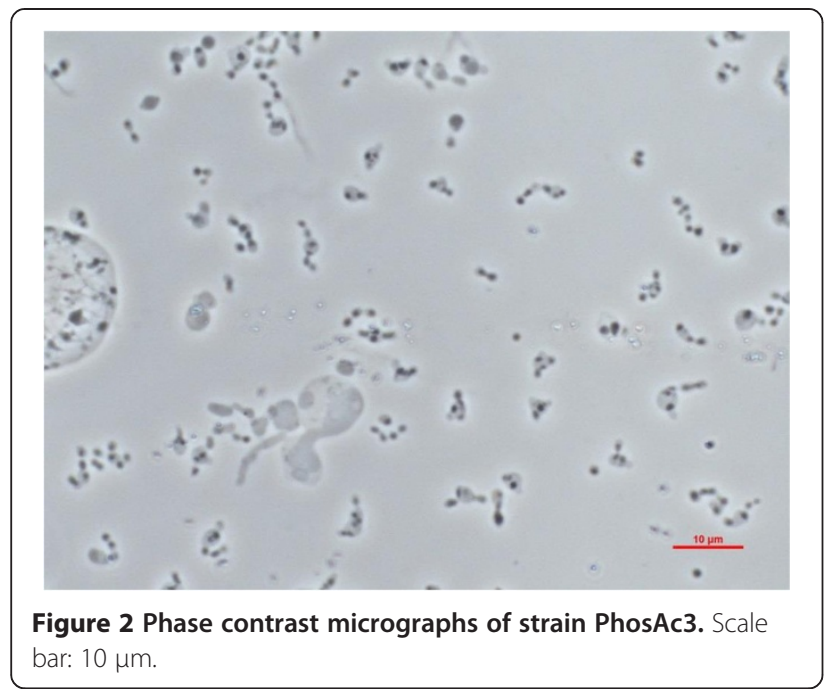

confirmed by re-sequencing of PCR products obtained using two primers pairs specifically designed to target the two 16S rRNA gene loci respectively). This situation contrasts with that of MesG1.Ag.4.2 ${ }^{\mathrm{T}}$, which was reported to harbor two distinct $16 \mathrm{~S}$ rRNA genes that are 99.1\% identical (Theba_0197 and Theba_1521). The two 16S rRNA genes of strain PhosAc3 share $99.2 \%$ identity with the sequence of MesG1Ag4.2. 16S rRNA gene A. Experiments conducted by the DSMZ (Deutsche Sammlung von Mikroorganismen und Zellkulturen $\mathrm{GmbH}$ ) Identification Service on PhosAc3 DNA revealed $78.7 \%$ of DNADNA re-association with $M$. prima MesG1.Ag.4. $2^{\mathrm{T}}$, which is a sufficient criterion to classify both strain in the same species. The phylogenetic position of strain PhosAc3 is shown in Figure 1.

Strain PhosAc3 is a Gram-negative, pleomorphic bacterium. Cells appeared mostly as chains with a rod to coccoid shape of 2-4 $\mu \mathrm{m}$ long and 1-2 $\mu \mathrm{m}$ in diameter (Figure 2). They were non-motile. Strain PhosAc3 is a strict anaerobe. It is a mesophilic bacterium with an optimal growth temperature at $40^{\circ} \mathrm{C}$ (range $30-50^{\circ} \mathrm{C}$ ). Additional analyses were performed to complete the characterisation of strain PhosAc3 using the same experimental procedures as detailed previously [3,4]. The optimal growth $\mathrm{NaCl}$ concentration was found at $2 \mathrm{~g}$. $\mathrm{L}^{-1}$ (range $0-30$ g. $\left.\mathrm{L}^{-1}\right)$. The optimum $\mathrm{pH}$ range for growth was 6.9 (range 6.7-7.9). Elemental sulfur $\left(10 \mathrm{~g}\right.$. $\left.\mathrm{L}^{-1}\right)$ was used as terminal electron acceptor, but not thiosulfate, sulfate or sulfite. Strain PhosAc3 used poorly yeast extract but requires it at low concentration (at $0.5 \mathrm{~g}$. $\mathrm{L}^{-1}$ ) to grow on sugars, peptides and organic acids (arabinose, fructose, glucose, maltose, mannose, raffinose, saccharose, xylose, cellobiose, peptone, lactate and pyruvate) probably as vitamins and other growth factor sources. In contrast, the following
Table 1 Classification and general features of Mesotoga strain PhosAc3

\begin{tabular}{|c|c|c|c|}
\hline MIGS ID & Property & Term & $\begin{array}{l}\text { Evidence } \\
\text { code }^{a}\end{array}$ \\
\hline & \multirow{8}{*}{$\begin{array}{l}\text { Current } \\
\text { classification }\end{array}$} & Domain Bacteria & TAS [6] \\
\hline & & Phylum Thermotogae & TAS [7] \\
\hline & & Class Thermotogae & $\operatorname{TAS}[7,8]$ \\
\hline & & Order Thermotogales & $\operatorname{TAS}[7,9]$ \\
\hline & & Family Thermotogaceae & $\operatorname{TAS}[7,10]$ \\
\hline & & Genus Mesotoga & TAS [4] \\
\hline & & Species Mesotoga prima & IDA \\
\hline & & PhosAc3 & TAS [3] \\
\hline & Gram stain & Gram - negative & IDA \\
\hline & Cell shape & $\begin{array}{l}\text { Rod to coccoid with } \\
\text { spheroids }\end{array}$ & TAS [3] \\
\hline & Motility & Non-motile & IDA \\
\hline & Sporulation & Non-sporulating & IDA \\
\hline & $\begin{array}{l}\text { Temperature } \\
\text { range }\end{array}$ & $30^{\circ} \mathrm{C}$ to $50^{\circ} \mathrm{C}$ & TAS [3] \\
\hline & $\begin{array}{l}\text { Optimum } \\
\text { temperature }\end{array}$ & $40^{\circ} \mathrm{C}$ & IDA \\
\hline & $\begin{array}{l}\text { pH range; } \\
\text { Optimum }\end{array}$ & & \\
\hline & Carbon source & $\begin{array}{l}\text { Acetate as carbon source, } \\
\text { Sugars (pentoses and } \\
\text { hexoses) and small organic } \\
\text { acids (e.g. lactate, pyruvate) } \\
\text { as energy sources }\end{array}$ & TAS [3] \\
\hline MIGS-6 & Habitat & $\begin{array}{l}\text { Mesothermic anaerobic } \\
\text { reactor }\end{array}$ & TAS [3] \\
\hline MIGS-6.3 & Salinity & 0 to $3 \%$ (optimum $0.2 \%$ ) & IDA \\
\hline MIGS-22 & Oxygen & Anaerobic & TAS [3] \\
\hline MIGS-15 & $\begin{array}{l}\text { Biotic } \\
\text { relationship }\end{array}$ & Free living & TAS [3] \\
\hline MIGS-14 & Pathogenicity & Non-pathogen & NAS \\
\hline MIGS-4 & $\begin{array}{l}\text { Geographic } \\
\text { location }\end{array}$ & Tunis - Tunisia & TAS [3] \\
\hline MIGS-5 & $\begin{array}{l}\text { Sample collection } \\
\text { time }\end{array}$ & 2008 & IDA \\
\hline \multirow{2}{*}{$\begin{array}{l}\text { MIGS-4.1 } \\
\text { MIGS-4.2 }\end{array}$} & Latitude & 32.38639 & IDA \\
\hline & Longitude & 11.45833 & IDA \\
\hline MIGS-4.4 & Altitude & 3 meters & IDA \\
\hline
\end{tabular}

${ }^{a}$ Evidence codes - IDA: Inferred from Direct Assay; TAS: Traceable Author Statement (i.e., a direct report exists in the literature); NAS: Non-traceable Author Statement (i.e., not directly observed for the living, isolated sample, but based on a generally accepted property for the species, or anecdotal evidence). These evidence codes are from of the Gene Ontology project [11].

substrates were not utilized: galactose, lactose, ribose, gelatin, casein, xylan, cellulose, acetate, butyrate, fumarate, succinate, ethanol, methanol, 1-propanol, and propionate. No growth by fermentation was observed with any combination of yeast extract and peptides or sugars in the absence of elemental sulfur, contrasting with what 
Table 2 Project information

\begin{tabular}{lll}
\hline MIGS ID & Property & Term \\
\hline MIGS 31 & Finishing quality & High-quality draft \\
MIGS 28 & Libraries used & $\begin{array}{l}\text { 454 paired-end 8- kb } \\
\text { non-cloned libraries }\end{array}$ \\
MIGS 29 & Sequencing platform & 454 GS FLX Titanium \\
MIGS 31.2 & Fold coverage & $49 \times$ \\
MIGS 30 & Assemblers & Celera \\
MIGS 32 & Gene calling method & AmiGene 2.0 and IMG/ER \\
& Locus Tag & PHOSAC3 \\
& Genbank ID & CARH01000001 to \\
& & CARH01000099 \\
& Genbank date of release & April 10, 2013 \\
& GOLD ID & Gp0041593 \\
& BIOPROJECT & \\
& Project relevance & Evolution (thermophily/ \\
& & mesophily), Bioremediation \\
MIGS 13 & Source material identifier & DSM 24444 \\
\hline
\end{tabular}

was reported for M. prima strain MesG1Ag4.2 (Additional file 1: Table S1). Surprisingly, acetate was also required at low concentration $(2 \mathrm{mM})$ to initiate growth most likely to serve as carbon source for anabolism and thus was latter systematically added to the culture medium. End products of sugar metabolism were acetate and $\mathrm{CO}_{2}$. Sulfide production resulted from reduction of elemental sulfur. In any conditions of cultures, hydrogen was detected only as traces with concentrations around $1 \mu \mathrm{M}$ measured in the gas phase. Finally, no growth was detected with $\mathrm{H}_{2} / \mathrm{CO}_{2}$ gas $(200 \mathrm{kPa})$ in the headspace, with or without acetate added to the culture medium. All these informations on strain PhosAc3 are summarized in Table 1.

\section{Chemotaxonomic data}

The fatty acid analysis was performed by the DSMZ on a PhosAc3 culture stopped at the end of exponential phase. Fatty acids were extracted using the method of Miller [12], analyzed by gas chromatography (gas chromatograph, model $6890 \mathrm{~N}$, Agilent Technologies) and the resulting profile was determined using the Microbial Identification System (MIDI, Sherlock Version 6.1; database, TSBA40). The fatty acid pattern of strain Phos Ac3 was similar to that of $M$. infera (Additional file 1: Table S2). In contrast to these bacteria, C14 was not detected in M. prima type species (MesG1.Ag.4.2 ${ }^{\mathrm{T}}$ ) thus suggesting that strain PhosAc3 should be considered as novel ecotype of $M$. prima species.

\section{Genome sequencing information Genome project history}

This organism was selected for sequencing on the basis of its environmental and biotechnological relevance to issues in global carbon cycling, bioremediation of polluted soils and its significance in studying the evolutionary mechanisms of adaptation to moderate temperatures [13]. The genome project and an improved-high-qualitydraft genome sequence have been deposited in the GOLD and IMG databases respectively. A summary of the project information is shown in Table 2.

\section{Growth conditions and DNA isolation}

Genomic DNA was isolated from an exponentially growing culture of strain PhosAc3 using the protocol of Marteinsson et al. [14].

\section{Genome sequencing and assembly}

De novo whole-genome shotgun sequencing was performed by combining a single and a long paired end (8 kbp) non-cloned libraries sequencing using the Roche Titanium pyrosequencing GS FLX+ technology (MWG Eurofins). This produced 350,813 reads with an average length of $439 \mathrm{bp}$ for a total number of sequenced bases of 154,143,916 representing a sequencing depth of 49x. Using Celera Assembler software (v.6.1) both data sets could be assembled into four scaffolds including 14 large contigs (>1,000 bp) and 127 small contigs.

\section{Genome annotation}

Gene predictions annotation and comparative genomic analyses were performed using the MicroScope annotation platform [15]. The predicted CDSs were translated and used to search the National Center for

Table 3 Genome statistics for M. prima strain PhosAc3

\begin{tabular}{ll}
\hline Attribute & Value \\
\hline Genome size $^{\mathrm{a}}$ (bp) & $3,113,612$ \\
DNA coding region (bp) & $2,646,577$ \\
DNA G + C content (bp) & $1,407,041$ \\
DNA scaffolds & 130 \\
Total genes & 3,123 \\
Protein-coding genes & 3,051 \\
RNA genes & 72 \\
Pseudo genes & 78 \\
Genes in internal clusters & $\mathrm{ND}$ \\
Genes with function prediction & 2,115 \\
Genes assigned to COGs & 1758 \\
Genes assigned Pfam domains & 2,173 \\
Genes with signal peptides & 77 \\
Genes with transmembrane helices & 813 \\
CRISPR repeats & 9 \\
\hline
\end{tabular}

${ }^{\mathrm{a}}$ Or 3,243,715 bp without undertermined pb. ${ }^{\mathrm{b}}$ Non-coding RNA $=17$. ${ }^{\mathrm{c}} \mathrm{rRNA}=4$ copies of 5S, 2 copies of $16 \mathrm{~S}$ and 3 copies of $23 \mathrm{~S}$ rRNA, tRNA $=47$. ND: not determined. 
Biotechnology Information non-redundant database, UniProt, TIGRFam, Pfam, PRIAM, KEGG, COGs, and InterPro. These data sources were combined to assert a product description for each predicted protein. Non-coding genes and miscellaneous features were predicted using tRNAscan-SE, RNAMMer, Rfam, TMHMM, and signalP. Additional gene prediction analysis and functional annotation were performed within the Integrated Microbial Genomes Expert Review platform [16]. CRISPR were searched using CRISPRFinder [17]. Table 3 presents the project information and its association with MIGS version 2.0 compliance [18].

\section{Genome properties}

The overall genome size estimated for $M$. prima strain PhosAc3 is 3,113,612 bp, significantly larger than that of the M. prima type strain MesG1.Ag.4.2
(2,974,229 bp) [19] and is composed of a unique circular chromosome (no plasmid was found in contrast to MesG1.Ag.4. $2^{\mathrm{T}}$ ). The average genome $\mathrm{G}+\mathrm{C}$ content of strain PhosAc3 of $45.19 \%$ is close to that of MesG1.Ag. $4.2^{\mathrm{T}}$ (45.45\%). It contains two ribosomal operons, 47 tRNAs and 3,051 predicted proteincoding genes (Table 3; Figure 3).

\section{Insights from the genome sequence}

Like Mesotoga prima (strain MesG1.Ag.4. $2^{\mathrm{T}}$ ), Mesotoga strain PhosAc3 possesses a significantly larger genome (3.11 and 2.97 Mb respectively) than their thermophilic counterparts within the Thermotogales whose genome size ranged from 1.86 to $2.30 \mathrm{Mb}$. Of the 3051 protein encoding genes (CDS) of strain PhosAc3, 2392 (78.4\%) have their best homologs (satisfying the bi-directional best hit criterion) in the complete genome of $M$. prima and are clustered in

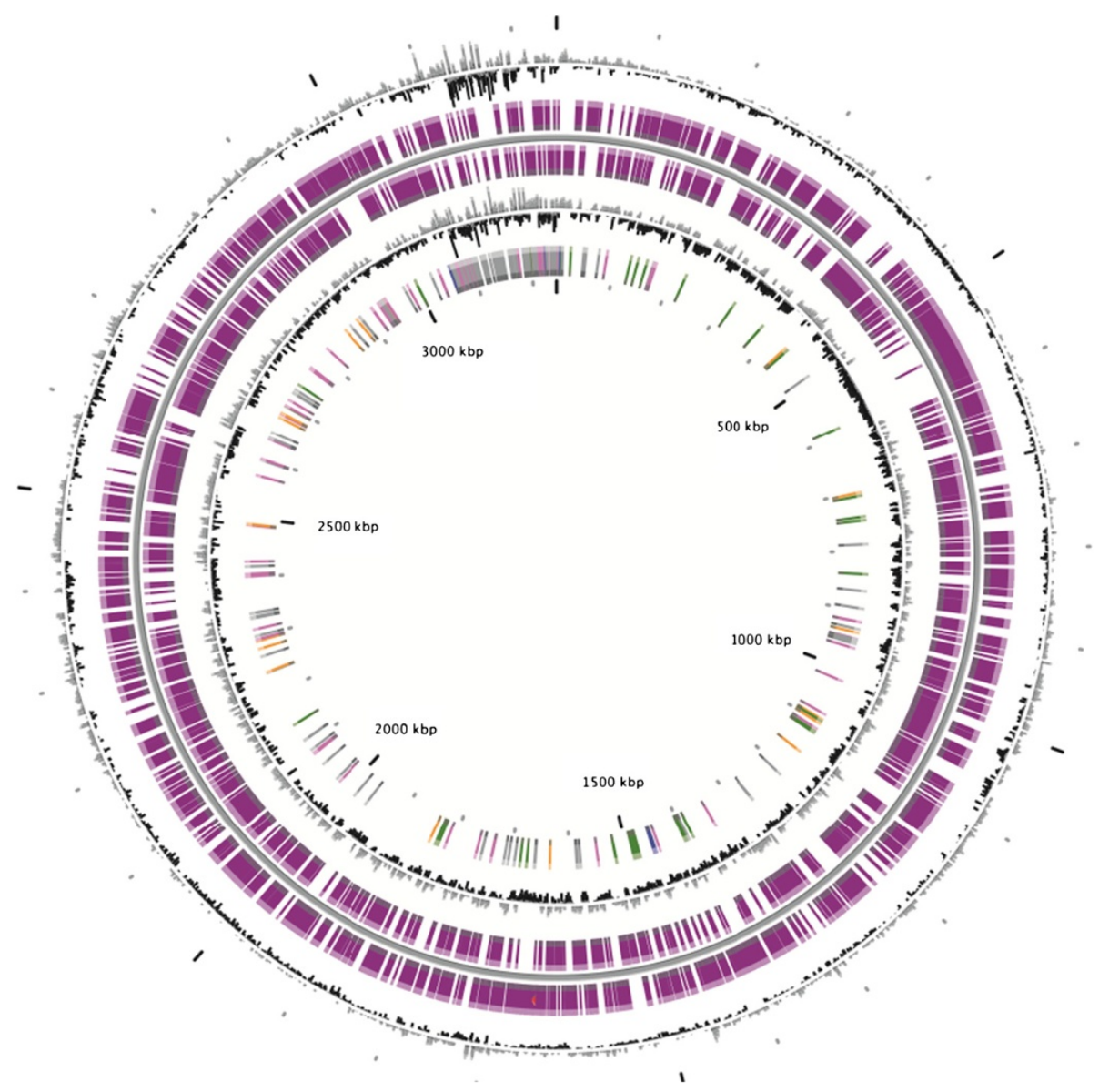

Figure 3 Circular representation of the Mesotoga strain PhosAc3 chromosome. Circles display (from the outside): (1) GC percent deviation (GC window - mean GC) in a 1000-bp window, (2) Predicted CDSs transcribed in the clockwise direction, (3) Predicted CDSs transcribed in the counterclockwise direction. Genes displayed in (2) and (3) are color-coded according different categories. Red and blue: MaGe validated annotations, orange: MicroScope automatic annotation with a reference genome, purple: Primary/Automatic annotations. (4) GC skew (G + C/G-C) in a 1000-bp window. (5) rRNA (blue), tRNA (green), misc_RNA (orange), Transposable elements (pink) and pseudogenes (grey). 


\begin{tabular}{|c|c|c|c|}
\hline Code & Value & $\%$ age & Description \\
\hline J & 133 & 7.01 & Translation, ribosomal structure and biogenesis \\
\hline A & 1 & 0.03 & RNA processing and modification \\
\hline K & 102 & 5.37 & Transcription \\
\hline L & 114 & 6.01 & Replication, recombination and repair \\
\hline B & 2 & 0.07 & Chromatin structure and dynamics \\
\hline D & 15 & 0.79 & $\begin{array}{l}\text { Cell cycle control, cell division, chromosome } \\
\text { partitioning }\end{array}$ \\
\hline V & 39 & 2.05 & Defense mechanisms \\
\hline $\mathrm{T}$ & 52 & 2.74 & Signal transduction mechanisms \\
\hline M & 92 & 4.85 & Cell wall/membrane/envelope biogenesis \\
\hline N & 6 & 0.32 & Cell motility* \\
\hline$U$ & 20 & 1.05 & Intracellular trafficking, secretion, and vesicular \\
\hline C & 117 & 6.16 & Energy production and conversion \\
\hline G & 243 & 12.80 & Carbohydrate transport and metabolism \\
\hline E & 229 & 12.07 & Amino acid transport and metabolism \\
\hline $\mathrm{F}$ & 57 & 3 & Nucleotide transport and metabolism \\
\hline $\mathrm{H}$ & 48 & 2.53 & Coenzyme transport and metabolism \\
\hline I & 43 & 2.27 & Lipid transport and metabolism \\
\hline P & 119 & 6.27 & Inorganic ion transport and metabolism \\
\hline Q & 22 & 1.16 & $\begin{array}{l}\text { Secondary metabolites biosynthesis, } \\
\text { transport and catabolism }\end{array}$ \\
\hline $\mathrm{R}$ & 254 & 12.91 & General function prediction only \\
\hline S & 141 & 7.43 & Function unknown \\
\hline J & 133 & 7.01 & Translation, ribosomal structure and biogenesis \\
\hline- & 1365 & 43.71 & Not in COG \\
\hline
\end{tabular}

The total is based on the total number of protein coding genes in the annotated genome. *Cell motility COG categories may also includes genes involved in secretion systems such as TSS2. This can explain the occurrence of genes of this category in the genome of strain PhosAc3 whilst this bacterium is non-motile.

273 syntons (cluster of at least two contiguous genes) in the two strains (SM Figure 1). For comparison sake, the two Mesotoga strains, MesG1.Ag.4.2 ${ }^{\mathrm{T}}$ and PhosAc3, share respectively 1468 and 1542 CDS with the closely related species Kosmotoga olearia strain TBF 19.5.1 (SM Figure 1). It seems that the supplementary genes found in Mesotoga strain PhosAc3 (not present in $K$. olearia) have been acquired by LGT mostly from mesophilic members of the Firmicutes (peculiarly within the Clostridiales order) to the Mesotoga (data not shown) with whom they share the same microbial habitat [19]. As previously observed for Mesotoga prima strain MesG1.Ag.4.2 $2^{\mathrm{T}}$, the largest fractions of the genes presumably acquired by LGT are involved in amino acids transport and metabolism (COG category E), secondary metabolite biosynthesis (COG category $\mathrm{Q}$ ) and signal transduction mechanisms (COG category $\mathrm{T}$ ) (Table 4; data not shown). Of the 659 genes of Mesotoga strain PhosAc3 with no detectable homologs in M. prima strain MesG1. Ag. $4.2^{\mathrm{T}}$, the majority $(65 \%)$ are annotated as unknown function proteins, $58(8,8 \%)$ correspond to transposons and the rest to poorly characterized functions (COG categories $S$ and $R$ ).

\section{Conclusion}

Based on taxonomic and genomic criteria, Mesotoga strain PhosAc3 should be considered a novel strain of the M. prima species. Besides numerous similarities, both strains exhibit clear differences in their phenotypic features and even to their gene content. They may therefore represent distinct ecotypes as previously defined [20, 21]. Strain PhosAc3, like M. infera, is capable of significant growth on simple substrates (sugars and organic acids) only in the presence of elemental sulfur as terminal electron acceptor suggesting that these substrates are oxidized rather than fermented. This sharply contrasts with the reported fermentative metabolism of sugars of $M$. prima type species (strain MesG1.Ag.4.2 ${ }^{\mathrm{T}}$ ). Other differences between strain PhosAc3 and M. prima strain MesG1. Ag. $4.2^{\mathrm{T}}$ include the end products of sugar metabolism, the optimum $\mathrm{NaCl}$ concentration for growth and the range of electron acceptors used (Table 1). The availability of the genome sequences of two Mesotoga strains offers a good opportunity to look in further details the genomic determinants that may be responsible of the metabolic differences observed between the two strains. Moreover, the comparison with other Thermotogales genomes should bring relevant information regarding the bacterial adaptation to novel ecological niches (from hot to mesothermic biotopes) and the importance of lateral gene transfer in such evolutionary processes [13].

\section{Additional file}

Additional file 1: Table S1. Differential characteristics between Mesotoga prima strains and $\mathbf{M}$. infera. Table S2. Fatty acids composition of Mesotoga prima strains and $M$. infera. Figure S1. Number of common (core) or strain-specific genes in Mesotoga strains and Kosmotoga olearia TBF 19.5.1.

\section{Competing interests}

The authors declare that they have no competing interests.

\section{Authors' contributions}

WB, KF and MLF performed experiments to complete the characterization of strain PhosAc3. WB and KF prepared genomic DNA of strain PhosAc3 for sequencing at GATC. GE and JLM processed the raw data through annotation pipelines. GE and AD did expert annotation searches. CB and AP performed phylogenetic analyses. CP, representing PROTEUS Cie, funded the project. GE and BO drafted the paper. All authors read and approved the final manuscript.

\section{Acknowledgments}

Sequencing cost was supported by Protéus SA. We thank Zoe Rouy from the MicroScope team for providing access to this powerful annotation platform. C.B.-A. is member of the Institut Universitaire de France. C. B-A is funded by the ANR-10-BINF-01-01 (Ancestrome) grants. 


\section{Author details}

'Aix-Marseille Université, Université du Sud Toulon-Var, CNRS/INSU, IRD, Mediterranean Institute of Oceanography (MIO), UM 110, F-13288, Marseille cedex 09, France. ${ }^{2}$ Laboratoire d'Ecologie et de Technologie Microbienne, Institut National des Sciences Appliquées et de Technologie, Faculté des Sciences de Carthage, Centre Urbain Nord, BP 676, 1080 Tunis, Tunisia. ${ }^{3}$ CNRS, UMR 5558, Laboratoire de Biométrie et Biologie Evolutive, Université de Lyon, Université Lyon 1, 43 boulevard du 11 novembre 1918, F-69622 Villeurbanne, France. ${ }^{4}$ Protéus SA, 70 Allée Graham Bell, F-30035 Nîmes, France. ${ }^{5}$ Aix-Marseille Université, CNRS, LCB-UMR7283, F-13009 Marseille, France.

Received: 25 May 2014 Accepted: 30 November 2014 Published: 1 May 2015

\section{References}

1. Nesbo CL, Dlutek M, Zhaxybayeva O, Doolittle WF. Evidence for existence of "mesotogas", members of the order Thermotogales adapted to low-temperature environments. Appl Environ Microbiol. 2006;72:5061-8.

2. Chouari R, Le Paslier D, Daegelen P, Ginestet P, Weissenbach J, Sghir A Novel predominant archaeal and bacterial groups revealed by molecular analysis of an anaerobic sludge digester. Environ Microbiol. 2005;7:1104-15.

3. Ben Hania W, Ghodbane R, Postec A, Brochier-Armanet C, Hamdi M, Fardeau $M-L$, et al. Cultivation of the first mesophilic representative ("Mesotoga") within the order Thermotogales. Syst Appl Microbiol. 2011;34:581-5.

4. Nesbo CL, Bradnan DM, Adebusuyi A, Dlutek M, Petrus AK, Foght J, et al. Mesotoga prima gen. nov., sp nov., the first described mesophilic species of the Thermotogales. Extremophiles. 2012;16:387-93.

5. Ben Hania W, Postec A, Aullo T, Ranchou-Peyruse A, Erauso G, Brochier-

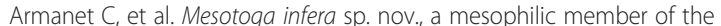
order Thermotogales, isolated from an underground gas storage aquifer. Int J Syst Evol Microbiol. 2013;63:3003-8.

6. Woese CR, Kandler O, Wheelis ML. Towards a natural system of organisms: proposal for the domains Archaea, Bacteria, and Eucarya. Proc Natl Acad Sci U S A. 1990;87:4576-9.

7. Reysenbach A. Phylum Bll. Thermotogae phy. nov. In: Boone DR, Castenholz RW, Garrity GM, editors. Bergey's Manual ${ }^{\circledR}$ of Systematic Bacteriology. Volume Volume One : The Archaea and the Deeply Branching and Phototrophic Bacteria. New York: Springer; 2001. p. 369-87.

8. Reysenbach A. Class I. Thermotogae class nov. In: Boone DR, Castenholz RW, Garrity GM, editors. Bergey's Manual ${ }^{\circledR}$ of Systematic Bacteriology. Volume Volume One: The Archaea and the Deeply Branching and Phototrophic Bacteria. New York: Springer; 2001. p. 369-70.

9. Reysenbach A. Order I. Thermotogales ord. nov. In: Boone DR, Castenholz RW, Garrity GM, editors. Bergey's Manual ${ }^{\circledR}$ of Systematic Bacteriology. Volume Volume One : The Archaea and the Deeply Branching and Phototrophic Bacteria. New York: Springer; 2001. p. 369-70.

10. Reysenbach A. Thermotogaceae fam. nov. In: Boone DR, Castenholz RW, Garrity GM, editors. Bergey's Manual ${ }^{\oplus}$ of Systematic Bacteriology. Volume Volume One: The Archaea and the Deeply Branching and Phototrophic Bacteria. New York: Springer; 2001. p. 369-70.

11. Ashburner M, Ball CA, Blake JA, Botstein D, Butler H, Cherry JM, et al. Gene ontology: tool for the unification of biology. The gene ontology consortium. Nat Genet. 2000;25:25-9.

12. Miller LT. Single derivatization method for routine analysis of bacterial whole-cell fatty acid methyl esters, including hydroxy acids. J Clin Microbiol. 1982;16:584-6.

13. Zhaxybayeva O, Swithers KS, Lapierre P, Fournier GP, Bickhart DM, DeBoy RT, et al. On the chimeric nature, thermophilic origin, and phylogenetic placement of the Thermotogales. Proc Natl Acad Sci U S A. 2009;106:5865-70.

14. Marteinsson V, Watrin L, Prieur D, Caprais J-C, Raquenès G, Erauso G. Sulfur-metabolizing hyperthermophilic anaerobic Archaea isolated from hydrothermal vents in the Southwestern Pacific Ocean. Int J Syst Bacteriol. 1995;45:623-32

15. Vallenet D, Engelen S, Mornico D, Cruveiller S, Fleury L, Lajus A, et al. MicroScope: a platform for microbial genome annotation and comparative genomics. Database (Oxford). 2009:2009:bap021. Epub 2009 Nov 25.

16. Markowitz VM, Chen I-MA, Palaniappan K, Chu K, Szeto E, Grechkin Y, et al. IMG: the integrated microbial genomes database and comparative analysis system. Nucleic Acids Res. 2012;40:D115-22.
17. Grissa I, Vergnaud G, Pourcel C. CRISPRFinder: a web tool to identify clustered regularly interspaced short palindromic repeats. Nucleic Acids Res. 2007;35:W52-7.

18. Field D, Garrity G, Gray T, Morrison N, Selengut J, Sterk P, et al. The minimum information about a genome sequence (MIGS) specification. Nat Biotechnol. 2008:26:541-7.

19. Zhaxybayeva O, Swithers KS, Foght J, Green AG, Bruce D, Detter C, et al. Genome sequence of the mesophilic Thermotogales Bacterium Mesotoga prima MesG1.Ag.4.2 reveals the largest Thermotogales genome to date. Genome Biol Evol. 2012;4:700-8.

20. Fenchel T. Microbiology. Biogeography for bacteria. Science. 2003;301:925-6.

21. Nesbo CL, Dlutek M, Doolittle WF. Recombination in Thermotoga: implications for species concepts and biogeography. Genetics. 2006;172:759-69.

doi:10.1186/1944-3277-10-12

Cite this article as: Ben Hania et al:: Draft genome sequence of Mesotoga strain PhosAC3, a mesophilic member of the bacterial order Thermotogales, isolated from a digestor treating phosphogypsum in Tunisia. Standards in Genomic Sciences 2015 10:12.

\section{Submit your next manuscript to BioMed Central and take full advantage of:}

- Convenient online submission

- Thorough peer review

- No space constraints or color figure charges

- Immediate publication on acceptance

- Inclusion in PubMed, CAS, Scopus and Google Scholar

- Research which is freely available for redistribution

Submit your manuscript at www.biomedcentral.com/submit
C Biomed Central 